\title{
Urgences
}

\section{Mon silence...}

\section{Jacinthe Caron}

\section{Numéro 9, 1er trimestre 1984}

URI : https://id.erudit.org/iderudit/025142ar

DOI : https://doi.org/10.7202/025142ar

Aller au sommaire du numéro

Éditeur(s)

Urgences

ISSN

0226-9554 (imprimé)

1927-3924 (numérique)

Découvrir la revue

Citer ce document

Caron, J. (1984). Mon silence... Urgences, (9), 79-82.

https://doi.org/10.7202/025142ar

Ce document est protégé par la loi sur le droit d'auteur. L'utilisation des services d'Érudit (y compris la reproduction) est assujettie à sa politique d'utilisation que vous pouvez consulter en ligne.

https://apropos.erudit.org/fr/usagers/politique-dutilisation/
Cet article est diffusé et préservé par Érudit.

Érudit est un consortium interuniversitaire sans but lucratif composé de l'Université de Montréal, l'Université Laval et l'Université du Québec à Montréal. Il a pour mission la promotion et la valorisation de la recherche. https://www.erudit.org/fr/ 


\section{JACINTHE CARON}


Mon silence est plein de cris

Cris de douleur et cris d'ennui

Cris de jour et cris de nuit

J'ai appris à être sage

On vous met le coeur en cage

Un voile noir par-dessus

Et l'oiseau qui pleure en vous

Qui gémit qui devient fou

L'oiseau passe, inaperçu

Ses ailes se décolorent

Et son ventre et tout son corps

L'oiseau se transparente

Quand on le juge à propos

On ouvre la porte à l'oiseau

Le voile tombe on lui dit: chante!

L'oiseau sort de sa cabane

Et ne vole ni ne plane

Et ne pleure ni ne rit

Et alors on est surpris

De le trouver si petit

Si pâle et si démuni

Et l'oiseau qui souffre en vous

Courbe la tête et les genoux

Honteux frileux tout nu

J'ai appris à être sage

On vous met le coeur en cage

Un voile noir par-dessus

Mon silence est plein de cris

Cris de douleur et cris d'ennui

Cris de jour et cris de nuit

Et le cri que j'écris

Est de silence, lui aussi... 
On dit que I'hiver chez nous

Est long de froids et de silences

Et qu'il ne reste pour faire les fous

Que les moineaux et les mésanges...

Je dis qu'au fond de moi

Les glaces s'éternisent

Et que même dans tes bras

Les rafales sont vives...

On dit que le printemps

Tache les rues et les bottines

Et qu'il est bien trop salissant

De se promener dans les villes...

Je dis qu'au fond de moi

Se cache une souillure

Tu peux changer les draps

Si cela te rassure...

On dit qu'il manque d'eau

Dès que l'été fait son ouvrage

Et I'on court au ruisseau

Tari, et c'est dommage...

Je dis qu'au fond de moi

Les cailloux s'entassent

Je t'en prie, arrose-moi

Mais je suis sèche, et lasse...

On dit qu'il fait trop noir

Quand s'amène l'automne

Et l'on allume tôt le soir

Avant que six heures sonne...

Je dis qu'au fond de moi

La veilleuse agonise

Je marche à petits pas

Et me heurte à ta chemise...

Dix fois, cent fois

Sur la couverture grise

Je t'ai dit ces mots-là

Peut-être faut-il que tu les lises... 
Trois enfants

Sont assis sur un banc.

Le père du premier

Est marchand de tissus

La mère fait de la couture

L'enfant est bien vêtu.

Le père du second

Élève des moutons

La mère tricote la laine

L'enfant est bien au chaud.

Le père du troisième

Conduit des camions

Mais il a quitté la maison

La mère a un amant

L'enfant est bien,

Tout simplement.

Mais la nuit

II rêve à des camions

... Évidemment... 